\title{
Studying Indicators of Amman Stock Exchange in Managing the Turnover of Shares forClothes and Leather Jordanian Companies
}

\author{
Dr. Mohammed Abdul majeed Al rgaibat \\ Researcher \\ Jordan \\ +962775406345 / mm.saho@yahoo.com \\ Dr.Ahmad Salem Alkhazali \\ Departement of Banking and Financial Sciences \\ +962777768448/ahmadkhzl@yahoo.com \\ Al al-Bayt University \\ P.O.BOX 130040 / Mafraq 25113, Jordan
}

\begin{abstract}
Securities market is the sale and purchase of all kinds (stocks and bonds), And because the stock market has a significant impact as economic the Amman Financial Market was established in 1978 and has succeeded in its early stages. It is divided into a primary market in which the shares are issued for the first time and a secondary market in which shares traded and the target of each investor traded in this market is To obtain maximum return ${ }^{l}$, the objective of each investor is to trade in this market to get the desired return as far as risk, and there are several sectors listed on the Amman Stock Exchange divided into three sectors
\end{abstract}

Keywords: Indicators, Amman Stock Exchange, Shares, Leather, Textile Jordanian Companies.

\section{Introduction}

Financial markets are the point of delivery between investors and companies by mobilizing savings and transforming them into investments that contribute to the economic development of countries and thus provide a solid base for the national economy ${ }^{2}$.Investment in ordinary shares is considered one of the types of investment in securities. Its basic concepts have been crystallized as a result of the development and maturity of financial markets ${ }^{3}$. The stock market in which securities are exchanged between the seller and the purchaser under the rules and provisions of the securities market is the sale and purchase of all kinds (stocks and bonds), And because the stock market has a significant impact as economicthe Amman Financial Market was established in 1978 and has succeeded in its early stages. It is divided into a primary market in which the shares are issued for the first time and a secondary market in which shares traded and the target of each investor traded in this market is To obtain maximum return ${ }^{4}$, the objective of each investor is to trade in this market to get the desired return as far as risk, and there are several sectors listed on the Amman Stock Exchange divided into three sectors(Financial Sector, Services Sector, Industrial Sector). The number of Jordanian public shareholding companies reached 238 public shareholding companies ${ }^{5}$.The industrial sector is one of the most important components of the Amman Financial Market, and it is able to support GDP. The importance of the industrial sector is expressed by supplying the national economy with the necessary commodities for consumption, employing large numbers of manpower and reducing unemployment.

\footnotetext{
${ }^{1}$ Shawawra, Khalil, (2008), The role of accounting information published in the prediction of stock prices in the Jordan Stock Exchange, applied study, Al Isra University, Amman, Jordan.

$=\left[7^{2}+\right.$ Al-Zu'bi, Saleh Ismail, (2000) The relationship between the values of the book value of the market value of the share and the share of the share of the profits and the return of the share, the unpublished MA thesis, Jordan University, Amman, Jordan

${ }^{3} \mathrm{Al}$-Tamimi,Fuad\&Izz,Osamah(2004), Investment in Securities: Analysis and Management, First Edition, Dar Al Masirah, Amman, Jordan.

${ }^{4}$ Shawawra, Khalil, (2008), The role of accounting information published in the prediction of stock prices in the Jordan Stock Exchange, applied study, Al Isra University, Amman, Jordan.

${ }^{5}$ Jordanian staff for money bills, July, 2014
} 
Therefore, this study comes to study the effect of stock indices (trading volume, number of shares and the number of executed contracts) on the turnover of the shares of the garment, leather and textile companies listed on the Amman Stock Exchange in 2014. The share price is the main engine of the company's capital. Investors can help to stimulate the movement of companies and improve their financial position. Stock prices can affect the volume of subscriptions and contracts executed at the same time on stock returns. There is no theory that high stock prices are higher than lowpriced stocks or vice versa.

\section{Problem of the study.}

The stock market is an important part of the economic activities through trading in securities (stocks and bonds), the volume of investment, and the number of stocks executed in this market. (2000-2016). There are several factors involved in determining the prices of market shares. The problem of the study can be formulated through the following questions:

1. Is there a statistically significant effect at the level of (5\%) of the volume of trading on the turnover of the shares of the garment, leather and textile companies listed on the Amman Stock Exchange?

2. Is there a statistically significant effect at the level of $(5 \%)$ of the number of shares traded on the turnover of the shares of the garment, leather and textile companies listed on the Amman Stock Exchange?

3. Is there a statistically significant effect at the level of (5\%) of the number of executed contracts on the turnover of the shares of the garment, leather and textile companies listed on the Amman Stock Exchange?

\section{Objectives of thestudy.}

The study aims at showing the effect of the stock exchange indices represented by: Volume, number of traded shares and number of executed contracts on the stock turnover of the Jordanian companies for the garment, leather and textile industries listed on the Amman Stock Exchange for 2014. And the return of shares and the fact that some investors in the conduct of sales and purchase transactions to protect themselves or to compensate them for some of the losses that occur as a result of the change in the turnover of shares and high stock prices and decline, this study to achieve the following objectives:

1. Know whether there is a significant statistical impact on the volume of trading on the turnover of the shares of the garment, leather and textile companies listed on the Amman Stock Exchange?

2. Identify whether there is a statistically significant effect of the number of shares traded on the turnover of the shares of the garment, leather and textile companies listed on the Amman Stock Exchange?

3. Identify whether there is a significant statistical effect on the number of contracts executed on the turnover of the shares of the garment, leather and textile companies listed on the Amman Stock Exchange?

\section{The Importance Of Study.}

The importance of this study stems from the importance of studying the factors influencing the turnover of the stock in the Amman Stock Exchange and the importance of determining the relationship between the volume of trading, the number of shares traded, the number of executed contracts and the turnover of the shares of the garment, leather and textile companies listed on the Amman Stock Exchange. Of the importance of the financial markets of their role in the transfer of funds from savers to investors, which positively affect the process of economic development, but this influence depends on the efficiency of these markets in the use of savings and employment in economic activity, which help to improve the efficiency of markets Yeh by determining the fair price of shares issued by the supply and demand, hence emerged the importance of studying the impact of the stock market indices(The volume of trading, the number of shares traded, and the number of executed contracts) in the rate of turnover of the stock, and the importance of the study by the benefit of many of the parties involved in the study such as investors, financial intermediaries, creditors, customers, government agencies involved, financial analysts and financial intermediaries, And related government agencies.

\section{Hypotheses of the study.}

This study is based on the following assumptions:

1. There is no significant statistical impact on the turnover on the shares of the garment, leather and textile industries listed on the ASE.

2. There is no statistically significant effect of the number of shares traded on the turnover of the shares of the garment, leather and textile companies listed on the Amman Stock Exchange.

3.There is no statistically significant effect of the number of contracts executed on the turnover of the shares of the garment, leather and textile companies listed on the Amman Stock Exchange. 


\section{Previous studies.}

There are a number of Arab and foreign studies that dealt with research in this field, including:

- ( Obedat\&Hmoud ,2014) ${ }^{6}$,Studying the Determinants of the Prices of Commercial Banks' Shares: An Empirical Study on the Amman Stock Exchange, which aimed at identifying the specific factors of share prices by applying to the Jordanian commercial banks the public shareholding in the ASE which consists of Of the (16) commercial banks during the period (1992-2014), The study used multiple linear regression model and included a number of independent variables namely volume, cash flow, dividend yield, distributed profit, book value, leverage. The results of the analysis showed no significant statistical relationship between the prices of commercial bank shares and independent factors Trading volume, liquidity, book value, and leverage. It also showed that there is a direct correlation between the prices of shares of commercial banks on the one hand and the profit distributed and return on the share, on the other hand, as evidenced by the results of the study that the independent variables combined have a significant impact on the dependent variable and the variables that occur in it.- (Youssef, 2011) ${ }^{7}$ Study, entitled: Determining Factors Affecting Stock Prices in Amman Stock Exchange, aimed at determining the most important factors affecting the return of shares in the ASE Leading reasons.(2)Yousef,DanahBassam(2010), "Factors Affecting Earnings Per Share in Amman Stock Exchange, Unpublished Master Thesis, Middle East University for Postgraduate Studies, Amman, Jordan.The study population of all companies listed on the Amman Stock Exchange from the industry, services, banks and insurance sector during the period 2000-2006, where the data obtained were inflation, GDP, share returns, return on equity , Profitability of the stock and dividends from the published financial reports of the sample companies. The study showed that there is a statistically significant relationship between the rate of inflation and the returns of shares and the absence of a statistically significant relationship between the deficit of the size of the GDP and the returns of shares.(Abu-Alhaiga,2010) The study of the distribution of profits and their impact on the market value of the shares. The aim of this study is to know the most important financing policies on which companies depend on providing liquidity for expansion and growth. The researcher studied all companies listed on the Amman Stock Exchange, Followed by a company from each sector. After collecting the necessary data, the appropriate analysis was used using the statistical analysis program, and showed that the retained earnings are one of the most important financing policies in companies so that they should be utilized optimally. Market Per share and the book value of the share. Companies in Jordan follow similar dividend distribution policies, as it has been shown that companies in Jordan have tried to maintain stable earnings per share and within certain limits.- ( Khrewish,2010)8The study of the effect of cash flows on the market value of shares of Jordanian banks and joint stock companies. The study aimed to measuring the relationship of cash flows with market value For shares of banks and financial institutions, the study was applied on 16 companies listed on the Amman Stock Exchange during the period 1998-2001, the results indicated that there is no statistically significant relationship between the market value of the share and net cash flows, and absence of a statistically significant relationship between the market value of the share and the ratio of net cash flows to equity, for several reasons, the study attributed the lack of knowledge of most investors to the benefits of cash flows when estimating the market value of shares and the weak efficiency of the Amman Stock Exchange.- ((Abu Hashish, 2003)9, entitled:The variables that affect stock prices in the stock market in the Hashemite Kingdom of Jordan, The study aimed at identifying the most important variables that affect stock prices in the stock market in the Hashemite Kingdom of Jordan, where the study was applied to the companies of the industry sector through the collection of data required for study through the website of the Securities Commission, the results showed that the share price on the Stock Exchange is directly linked to the earnings per share, net profit to equity, net profit to total assets, net profit to normal operating income, net cash flows to total assets, equity to total sources of funds, trading ratio, interest rate to total expenses, and market value to book value, as well as a significant relationship with each of the earnings per share, market value to book value, equity to total sources of funds,Profit to profit, net profit to total assets, as it is inversely correlated with fixed assets to total assets, total creditors to total sources of funds, and the ratio of wages to total expenditures.

\footnotetext{
${ }^{6}$ Obedat, Samir\&Hmoud, Safaa(2014), "Analysis of the Prices of Commercial Banks' Shares: An Empirical Study on the ASE", Journal of Human Sciences, Issue 46, 8th Year, pp. 1-20.

7. (Youssef, 2011) ${ }^{7}$ Study, entitled: Determining Factors Affecting Stock Prices in Amman Stock Exchange, aimed at determining the most important factors affecting the return of shares in the ASE Leading reasons.

${ }^{8}$ Khrewish, Hosni, Abdul MutiArsid, and Mahfouz Jouda,(1999), Investment and Finance between Theory and Practice, Dar Zahran Publishing and Distribution, Amman, Jordan.

${ }^{9}$ (Abu Hashish,Khaleel,2010), The role of published accounting information in the prediction of stock prices in the Jordanian Stock Exchange, Applied Study, Journal of Studies, Volume 6, Second Issue, pp. 165-179.
} 
(Haji and Jianguo, 2014)10, entitled:The Relationship of the Stock Market Prices on Exchange Rate and Market Capitalisation: the Case Dar es Salaam Stock Exchange in TanzaniaExchange in Tanzania.The study aimed to examine the relationship between the stock indicates in the Dar es Salaam Stock Exchange, and exchange rate and capital market of companies listed in the Dar es Salaam Stock Exchange, To achieve the objectives of the study, the data of the listed companies were obtained during the period 1999-2013, and the researchersusedthe multiple regression equations where the prices of shares of listed companies considered as a dependent variable and the exchange rates and the capital market are considered independent variables, the results of the statistical analysis showed that there is a positive relationship between the rate of exchange and the prices of companiesshares, There is also a positive correlation between capital markets and stock prices.(Leledakis et. al., 2010)11, entitled:Structural change in expected stock Returneestructural changes in anticipated stock returns. The study aimed to assessing the importance of macroeconomic factors affecting expected stock returns. The study was applied to a sample of companies in the United States of America during The period (1991-2004), after the necessary data collection was performed multiple regression analysis of the study variables, the results showed that there are two factors that can explain the significant proportion of cross-sectional variability of individual stock returns are: changes in short-term interest rates and company size effects, and that there is great importance between the returns of stocks and economic effects, interest rates positively affect earnings per share.(McMillan, 2015) 12, entitled:"Time difference in the cointegrating relationship between stock prices and economic activity" The study aimed to identify the relationship between the market share of shares and the interest rates of listed companies In the United States, during the period (1971-2000). It was found that there is a positive correlation between stock price and industrial production, and that there is an inverse relationship between stock prices and interest rates.

\section{Methodology of the study.}

This chapter deals with the methodology of the study by reviewing the stages and steps taken to achieve the objectives of the study, which is to determine the effect of the stock indexes on the turnover of shares in the clothing, leather and textile companies during the period 2000-2016.Society and sample of the study. The study population consists of Jordanian industrial joint stock companies listed on the Amman Stock Exchange, and its number (69) company, (Jordan Securities Commission, July 2014) distributed to (11) industrial sector. The sample of the study consisted of (6) clothing, leather and textile companies listed,which have been provided with financial statements for a consecutive period during the period (2000-2016), and they have the following conditions:- Have audited financial statements published during the study period (2000-2016).- Do not be merged with another company during the study period.- Its shares should be listed on the Amman Stock Exchange during the study period. Two companies that entered the Amman Stock Exchange recently (2006) were excluded and did not cover the study period, as result, the final sample for which data were available during the study period and the analysis on it became (4) companies with 52 observations during the study period.

\section{Model and study variables.}

The data required for this study will be collected from the financial reports of the sample companies of (4) companies listed on the Amman Stock Exchange for 2014 to reveal the data of the study variables as follows:

1. Compiling the financial data from the Jordanian Public Shareholding Companies Directory issued by the Amman Stock Exchange and from the financial reports of the companies from the period 2000-2016 which relate to the volume of trading (JD), the number of shares traded, the number of executed contracts, and the rate of shares turnover for each company in the sample.

2. Studying the effect of stock indexes on the rate of stock turnover in the financial market, according to the following simple regression equations:

Turnover Ratio $\%=\alpha+\beta 1$ Value Traded (JD) + Et

Turnover Ratio $\%=\alpha+\beta 1$ No. of Shares Traded. + Et

Turnover Ratio $\%=\alpha+\beta 1$ No. of Transactions + Et

\footnotetext{
${ }^{10}$ Haji, Iddi. Salum and Jianguo Wei (2014),The Relationship of the Stock Market Prices on Exchange Rate and Market Capitalisation: the Case Dar es Salaam Stock Exchange in Tanzania, Research Journal of Finance and Accounting, Vol.5, No.10, pp107-112)

${ }^{11}$ Leledakis, George,Tzavalis, Elia,Karanikaz, Evangelos,(2010), Structural change in expected stock returne , Jornal of Business Finance and Accounting, Athens, Greece, Electronic copy available at: http://ssrn.com/abstract=1905029

${ }^{12}$ McMillan, David (2015), Time variation in the cointegrating relationship between stock prices and economic activity , An Empirical Study of the U.S. market, South African Journal of Business Management, Vol. 42, No.3
} 
whereas:

Et: represents the random error

The following chart explains the relationship between the study variables.

Table 1 Independent variables and dependent variable

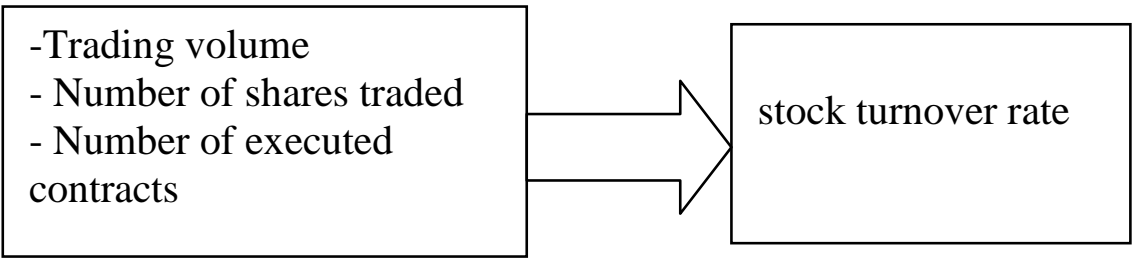

Table 1 shows the results of the descriptive analysis of the variables of the study sample, using the statistical analysis methods represented by the arithmetic mean, the standard deviation, the highest value and the lowest value. The table shows that the average of the shares turnover of the study sample was JD (101.11), and standard deviation (168.67), which Indicating that the average turnover of the shares of companies varied between ( 0.20 to 929.32). The higher average of share turnover of companies may be due to fluctuations in share prices from high and low.

Table (1)

Descriptive statistics of the study variables

\begin{tabular}{|l|l|l|l|l|}
\hline variable & $\begin{array}{l}\text { Arithmetic } \\
\text { mean }\end{array}$ & $\begin{array}{l}\text { standard } \\
\text { deviation }\end{array}$ & highest value & Lowest value \\
\hline Turnover rate & 101.11 & 168.67 & 929.32 & 0.20 \\
\hline $\begin{array}{l}\text { Traded volume } \\
\text { (JD) }\end{array}$ & 7104878 & 11099039 & 52067229 & 1590 \\
\hline $\begin{array}{l}\text { Number of } \\
\text { shares traded }\end{array}$ & $5,393,218$ & $8,995,697$ & $45,784,319$ & 2,750 \\
\hline $\begin{array}{l}\text { Number of } \\
\text { executed } \\
\text { contracts }\end{array}$ & 4263.5 & 5984.398 & 29427 & 6 \\
\hline
\end{tabular}

As shown in the previous table:

- The volume of trading in the Amman Financial Market for companies in the sample of the study included in the Amman Stock Exchange amounted to an average of (7104878) (JD), which is a high trading volume, with a standard deviation (11099039) indicating that there is a discrepancy between the sample companies in relation to this variable, The volume of trading in the Amman Financial Market for companies in the sample of the study included in the Amman Stock Exchange amounted to an average of (7104878) dinars, which is a high trading volume and a standard deviation (11099039), indicating the existence of disparities between the companies sample study in relation to this variable,the volume of trading for companies ranges from (1590 to 52067229).In terms of the number of shares traded, the results indicated that its average amounted $(5,393,218)$, with a standard deviation of $(8,995,697)$, ranged between $(2,750-45,784,319)$. This may indicate that the companies followed a different policy regarding the issue of traded shares, where the standard deviation was high, indicating the number of shares traded for the sample companies.- The largest standard deviations of the study variables were in the number of shares traded which reached $(8,995,697)$ and this means that this variable is the most dispersed variables.- 
The average number of contracts executed reached (4263.5) contracts and ranged between (6-29427) contract, which indicates that there is active trading in the ASE, and there are a large number of investors working on monitoring the prices of the shares of the Amman Stock Exchange and expected to have an impact on the average turnover of the stock in a soft relationship according to accounting theory.

\section{Degree of correlation between study variables.}

Table 2 shows Pearson correlation coefficients among the study variables, in which there is a lack of high correlation between the study variables to the extent that it can affect the results of the regression analysis.

Table (2)

Pearson correlation coefficients between study variables

\begin{tabular}{|l|l|l|l|}
\hline variable & Trading volume (JD) & $\begin{array}{l}\text { Number of shares } \\
\text { traded }\end{array}$ & $\begin{array}{l}\text { Number of executed } \\
\text { contracts }\end{array}$ \\
\hline Trading volume (JD) & 1 & & \\
\hline $\begin{array}{l}\text { Number of shares } \\
\text { traded }\end{array}$ & $0.560^{* *}$ & 1 & 1 \\
\hline $\begin{array}{l}\text { Number of executed } \\
\text { contracts }\end{array}$ & $0.663^{* *}$ & $0.557^{* *}$ & 1 \\
\hline
\end{tabular}

*** Correlation is significant at the 0.01 level (2-tailed).

From the previous table, there is no high correlation between the study variables to the extent that it can affect the results of regression analysis where the highest correlation between $(0.663)$ between the number of executed contracts and trading volume was statistically significant at (0.01), while the table shows that the lowest correlation Was between the number of executed contracts and the number of shares traded with Pearson correlation (0.557). This indicates the acceptance of the study variables and their suitability for regression analysis.

\section{Study hypotheses testing.1st Hypothesis:}

There is no statistically significant impact of the trading volume on thesharesturnover of the cloth, leather and textile industries listed on the Amman Stock Exchange.

Table (3) shows the results of the simple regression analysis of the volume of trading impact on the shares turnover in the cloth, leather and textile companies, showing that there is a statistically significant effect of trading volume on the share turnover. The correlation coefficient $(\mathrm{R}=0.01)$, at a significant level $(0.01)$, The coefficient of determination $\left(R^{2}\right)$ explains $(0.223)$ of the variance in the dependent variable, meaning that the value of about $(22 \%)$ of the changes in the turnover of the stock result from the change in trading volume, also the level of impact reach (0.488), and this is explained by the fact that a single increase in trading volume leads to an increase in the turnover of the stock at a rate of (0.488), the value of $\mathrm{F}(15.567)$ was statistically significant at (0.01).

Table (3)

Results of simple regression analysis of the independent variable volume trading

\begin{tabular}{|l|l|l|l|l|l|l|l||}
\hline $\begin{array}{l}\text { Independent } \\
\text { variable }\end{array}$ & $\begin{array}{l}\text { )R(correl } \\
\text { ation }\end{array}$ & $\begin{array}{l}\text { R }^{2} \\
\text { coefficient } \\
\text { of } \\
\text { determinat } \\
\text { ion }\end{array}$ & F value & $\begin{array}{l}\text { Sig. } \\
\text { Level of } \\
\text { significan } \\
\text { ce }\end{array}$ & $\begin{array}{l}\beta \mathrm{i} \\
\text { Regressi } \\
\text { on } \\
\text { coefficie } \\
\text { nt }\end{array}$ & T value & $\begin{array}{l}\text { Level of } \\
\text { significance }\end{array}$ \\
\hline $\begin{array}{l}\text { Trading } \\
\text { volume (JD) }\end{array}$ & 0.488 & 0.223 & 15.597 & 0.000 & 0.488 & 3.949 & 0.000 \\
\hline
\end{tabular}


Based on the foregoing, the 1st hypothesis is rejected and the alternative hypothesis is accepted that states "there is a statistically significant effect of the volume of trading on the turnover of the shares of cloth, leather and textile companies listed on the ASE."

\section{2nd hypothesis:}

There is no statistically significant effect of the number of shares traded on the turnover of the shares of the cloth, leather and textile companies listed on the Amman Stock Exchange.Table (4) shows the results of the simple regression analysis of the effect of the number of shares traded on the turnover of the shares in the cloth, leather and textile companies, showing that there is a statistically significant effect of the number of shares traded on the turnover of the share, the correlation coefficient (R) (0.592) was at a significant level (0.01), the coefficient of determination () explains the difference (0.337) of variance in the dependent variable, that is, approximately $(38 \%)$ of the changes in the share turnover are due to the change in the number of shares traded, as the level of impact (0.592) this is explained by the fact that a single increase in the number of traded shares increases the turnover of the stock by 0.592 . This confirms that the value of $\mathrm{F}$ (26.973) was statistically significant at (0.01).

Table (4)

Results of the simple regression analysis of the independent variable number of shares traded

\begin{tabular}{||l|l|l|l|l|l|l|l||}
\hline $\begin{array}{l}\text { Independent } \\
\text { variable }\end{array}$ & $\begin{array}{l}\text { )R(correl } \\
\text { ation }\end{array}$ & $\begin{array}{l})^{2} \\
\text { coefficient } \\
\text { of } \\
\text { determinat } \\
\text { ion }\end{array}$ & F value & $\begin{array}{l}\text { Sig. } \\
\text { Level of } \\
\text { significa } \\
\text { nce }\end{array}$ & $\begin{array}{l}\beta \mathrm{i} \\
\text { Regressi } \\
\text { on } \\
\text { coefficie } \\
\text { nt }\end{array}$ & T value & $\begin{array}{l}\text { Level of } \\
\text { significance }\end{array}$ \\
\hline $\begin{array}{l}\text { number of } \\
\text { shares traded }\end{array}$ & 0.592 & 0.337 & 26.973 & 0.000 & 0.592 & 5.194 & 0.000 \\
\hline
\end{tabular}

Based on the above, the first hypothesis is rejected and the alternative hypothesis is accepted. The statistical hypothesis is that "there is a statistically significant effect of the number of shares traded on the turnover of the shares of the cloth, leather and textile companies listed on the Amman Stock Exchange."3rd hypothesis: There is no significant effect of the number of contracts executed on the turnover of the shares of the cloth, leather and textile companies listed on the Amman Stock Exchange.Table (5) shows the results of the simple regression analysis of the effect of the number of contracts executed on the turnover of the shares in the cloth, leather and textile companies, showing that there is a statistically significant effect of the number of contracts executed on the share turnover rate. The correlation coefficient $(\mathrm{R}=0,488)$ at a significant level $(0.01)$, while the coefficient of determination $\left(R^{2}\right)$ explains the $(0.223)$ of the variance in the dependent variable, meaning that approximately $(22 \%)$ of the changes in the turnover of the stock result from the change in the number of executed contracts, and the level of impact $(\beta \mathrm{i}=0.488)$, which explains that the a single increase in the number of executed contracts increases the rate of the turnover of shares (0.48), confirming that $F$ value (15.621) was statistically significant at (0.01).

Table (5)

Results of the simple regression analysis of the independent variable Number of executed contracts

\begin{tabular}{|l|l|l|l|l|l|l|l||}
\hline $\begin{array}{l}\text { Independent } \\
\text { variable }\end{array}$ & $\begin{array}{l}\text { )R(correl } \\
\text { ation } \\
\text { coefficient } \\
\text { of } \\
\text { determinat } \\
\text { ion }\end{array}$ & F value & $\begin{array}{l}R^{2} \\
\begin{array}{l}\text { Level of } \\
\text { significa } \\
\text { nce }\end{array}\end{array}$ & $\begin{array}{l}\beta \mathrm{i} \\
\text { Regressi } \\
\text { on } \\
\text { coefficie } \\
\text { nt }\end{array}$ & T value & $\begin{array}{l}\text { Level of } \\
\text { significance }\end{array}$ \\
\hline $\begin{array}{l}\text { Number of } \\
\text { executed } \\
\text { contracts }\end{array}$ & 0.488 & 0.223 & 15.621 & 0.000 & 0.488 & 3.952 & 0.000 \\
\hline
\end{tabular}


Based on the above, the 3rd hypothesis is rejected and the alternative hypothesis is accepted that states: "There is a statistically significant effect of the number of contracts executed on the turnover of the shares of the cloth, leather and textile companies listed on the Amman Stock Exchange."

\section{Conclusions and recommendations}

\section{Introduction}

After analyzing the data obtained on the sample of the study in the previous chapter, this chapter presents the main results obtained based on the results of the analysis, in addition to presenting some recommendations that are considered to benefit some of the parties concerned.

\section{Results:}

1. The number of shares traded is one of the most influential in the stock market, affecting the turnover of shares of the cloth, leather and textile companies listed on the Amman Stock Exchange, While trading volume is the least influential.

2. There is a positive statistically significant effect of the volume of trading on the turnover rate of (48.8\%), and the volume of trading accounts for $(22.3 \%)$ of the changes in the turnover of shares in the clth, leather and textile companies listed on the ASE.

3. There was a positive effect of statistical significance of the number of shares traded on the turnover of (59.2\%), and the number of shares traded accounted for $(33.7 \%)$ of the changes in the turnover of shares in the cloth, leather and textile companies listed on the Amman Stock Exchange . 4. The number of contracts executed positively affects the turnover of shares at (48.8\%) and explains (22.3\%) of the changes in the turnover of shares in the cloth, leather and textile companies listed on the Amman Stock Exchange.

\section{Recommendations:}

1. Companies listed on the Amman Stock Exchange must present their data to investors and traders in the stock market for their importance in the investment process and their impact on stock prices.

2. The investor should make his investment decision based on more than one factor and a variable that affects the investment decision, and take the principle of diversification in his investment portfolio to minimize risks as much as possible.

3. The researchers should study other stock exchange indices that affect the share turnover rate (closing price, market value, number of shares subscribed ...) and all companies listed on the Amman Stock Exchange, with a cross-sectoral comparison.

\section{References:}

\section{First: Arabic References}

Abu Hashish, Khalil (2003), The Role of Accounting Information published in the Prediction of Stock Prices in the Jordanian Stock Exchange, Applied Study, Journal of Studies, Volume 6, Second Issue, pp. 165-179.

Tamimi, Fouad, and Asama Ezz, (2004), Investment in Securities: Analysis and Management, First Edition, Dar AlMasirah for Publishing and Distribution, Amman, Jordan.

Al-Henawi, Mohammed Saleh, et al. (2004), Investment in Shares and Bonds, First Edition, University House for Publishing and Distribution, Alexandria.

Hanafi, Abdul Ghaffar, (2006), Financial Management, Introduction to Decision Making, First Edition, University House for Publishing and Distribution, Alexandria.

Khuraish, Husni, Abdul MutiArsid, Mahfouz Jouda (1999), Investment and Finance between Theory and Practice, Dar Zahran Publishing and Distribution, Amman, Jordan.

Dagher, Mahmoud Mohamed, (2005), Financial Markets, Institutions, Bursat, Dar Al Shorouk Publishing and Distribution, Amman, Jordan

Al-Zu'bi, Saleh Ismail, (2000) The relationship between the value of the book value of the market value of the share and the share of the share of profits and the return of the share, unpublished MA thesis, Jordan University, Amman, Jordan

Shawawra, Khalil, (2008), The Role of Accounting Information in the Prediction of Stock Prices in the Jordan Stock Exchange, Applied Study, Al-Isra University, Amman, Jordan.

Amiri, Mohamed Ali, (2007), Financial Management, Dar Al-Maaishah for Publishing and Distribution, First Edition, Amman, Jordan. 
Obaidat, Samer and Hamoud, Safa (2010), "Analysis of the Prices of Commercial Banks' Shares: An Empirical Study in the ASE", Journal of Humanities, Issue 46, 8th Year, pp. 1-20.

The Judges, Kamal, (1997), "Public Shareholding Companies and Their Consideration of the Financial Market Assessment of their Shares", Yarmouk Research Journal, Volume 13, No. 1, pp. 211-165.

Iraq Stock Exchange Forum: www. Iraqsm.com/ vb / archive / index9 / 4/2012.

Al-Midan, Muhammad, (1989), Corporate Finance, First Edition, Dar Al-Maaishah for Publishing and Distribution, Amman, Jordan.

Youssef, DanhaBassam, (2007), "Factors Affecting Return on Stock in Oman Stock Exchange, Unpublished Master Thesis, Middle East University for Graduate Studies, Amman, Jordan.

\section{Second: Foreign References}

Archer, Stephen H.,\& Choate marc G. \&George Racette,(1979), Financial Management An Introduction, John Wiley \& Sons, New Yurok.

Haji, Iddi. Salum and Jianguo Wei (2014), The Relationship of the Stock Market Prices on Exchange Rate and Market Capitalisation: the Case Dar es Salaam Stock Exchange in Tanzania, Research Journal of Finance and Accounting, Vol.5, No.10, pp107-112.

Leledakis, George, Tzavalis, Elia, Karanikaz, Evangelos, (2006), Structural change in expected stock returne , Jornal of Business Finance and Accounting, Athens, Greece, Electronic copy available at: http://ssrn.com/abstract=1905029

Marsh ,Terry, (2006), The Role of Country and Industry Effects in Explaining Global Stock Returns , Stanford University, California, Electronic copy available at: http://ssrn.com/abstract=15601243

Martins, E. Galdi, F. Lima, G. \&Necyk G., (2006), "Empirical Evidence for models to estimate the cost of Equity Capital", Journal Brazilian Business Review. Vol. 3 No. 2, 2004. Pp 123- 138.

McMillan, David (2005), Time variation in the cointegrating relationship between stock prices and economic activity , An Empirical Study of the U.S. market, South African Journal of Business Management, Vol. 42, No.3 